RECASTING ISLAMIC LAW 



\section{RECASTING ISLAMIC LAW}

RELIGION AND THE NATION STATE IN EGYPTIAN CONSTITUTION MAKING

RACHEL M. SCOTT 
Copyright (C) 2021 by Cornell University

This book is freely available in an open access edition thanks to TOME (Toward an Open Monograph Ecosystem) - a collaboration of the Association of American Universities, the Association of University Presses, and the Association of Research Libraries - and the generous support of Virginia Tech. Learn more at the TOME website, available at: openmonographs.org.

The text of this book is licensed under a Creative Commons Attribution-NonCommercial-NoDerivatives 4.0 International License: https: / / creativecommons.org/ licenses/by-nc-nd/4.0/. To use this book, or parts of this book, in any way not covered by the license, please contact Cornell University Press, Sage House, 512 East State Street, Ithaca, New York 14850. Visit our website at cornellpress. cornell.edu.

First published 2021 by Cornell University Press

ISBN 978-1-5017-5397-8 (paperback)

ISBN 978-1-5017-5398-5 (PDF)

ISBN 978-1-5017-5399-2 (epub)

Library of Congress Control Number: 2020950257

Cover photograph: Revolutionary graffiti from Youssef al-Gindy Street, near Midan Tahrir, Cairo. Photograph taken by the author, May 2013. 
For Michael and Clea 
